\title{
Increased expression of heat shock protein-binding protein 1 and heat shock protein 70 in human hepatocellular carcinoma tissues
}

\author{
YUICHIRO YOKOYAMA ${ }^{1,2}$, YASUHIRO KURAMITSU ${ }^{1}$, MOTONARI TAKASHIMA $^{1,3}$, \\ MASANORI FUJIMOTO ${ }^{1}$, NORIO IIZUKA ${ }^{3}$, SHUJI TERAI ${ }^{2}$, KIWAMU OKITA $^{2}$, ISAO SAKAIDA ${ }^{2}$, \\ MASAAKI OKA ${ }^{3}$, DEBORAH A. RAYNES ${ }^{4}$, VINCE GUERRIERO ${ }^{4,5}$ and KAZUYUKI NAKAMURA ${ }^{1}$
}

\begin{abstract}
Departments of ${ }^{1}$ Biochemistry and Functional Proteomics, ${ }^{2}$ Gastroenterology and Hepatology, and ${ }^{3}$ Digestive Surgery, Yamaguchi University Graduate School of Medicine, Yamaguchi 755-8505, Japan; Departments of ${ }^{4}$ Animal Sciences, and ${ }^{5}$ Molecular and Cellular Biology, University of Arizona, Tucson, AZ 85721-0038, USA
\end{abstract}

Received November 27, 2007; Accepted December 28, 2007

\begin{abstract}
Heat shock protein-binding protein 1 (HspBP1) is a co-chaperone that inhibits heat shock $70-\mathrm{kDa}$ protein (Hsp70) activity. In mouse neuroblastomas and lung tumors, the protein levels of HspBP1 and Hsp70 are elevated by a similar amount compared to non-tumor tissues. However, no studies have been reported regarding the levels of HspBP1 in human cancer tissues. Our previous proteomic study demonstrated that the expression of Hsp70 was increased in human hepatitis $\mathrm{C}$ virus-related hepatocellular carcinoma (HCV-HCC) tissues. Here, we investigated the expression of HspBP1 in human HCV-HCC. Immunoblotting analysis of HspBP1 and Hsp70 was performed in human HCV-HCC tissues from 20 patients. In $80 \%$ of the patients, Hsp70 increased an average of 3.55 -fold, and in $50 \%$ of the patients, HspBP1 increased an average of 2.02-fold. Comparison and analysis of expression and clinical data revealed a significant difference between moderately-differentiated HCC and nontumor tissues. In addition, there was a significant difference between the ratio of HspBP1 to Hsp70 levels and tumor size $(<3 \mathrm{~cm}$ vs. $\geq 3 \mathrm{~cm})$ with larger tumors having a lower ratio. This ratio was significantly lower in moderately-differentiated HCC tissues than in non-tumor HCC tissues. In conclusion, HspBP1 was up-regulated in human $\mathrm{HCV}-\mathrm{HCC}$, an increase which correlated with the increase of Hsp70 levels. The ratio of HspBP1 to Hsp70 in HCC may provide novel information
\end{abstract}

Correspondence to: Professor K. Nakamura, Department of Biochemistry and Functional Proteomics, Yamaguchi University Graduate School of Medicine, 1-1-1 Minami-kogushi, Ube, Yamaguchi 755-8505, Japan

E-mail: nakamura@yamaguchi-u.ac.jp

Key words: heat shock protein-binding protein 1, heat shock protein 70 , hepatitis $\mathrm{C}$ virus, hepatocellular carcinoma concerning the characterization of tumors, tumor progression and resistance to treatment.

\section{Introduction}

Hepatocellular carcinoma (HCC) is one of the most malignant tumors worldwide. Most notably, chronic hepatitis and liver cirrhosis caused by infection with hepatitis $\mathrm{C}$ virus (HCV) are correlated with HCC in Japan. An urgent goal in this area is the identification of reliable biomarkers for the early diagnosis of HCC. Proteomic studies have been carried out to find new markers for HCC and to understand the pathogenesis of this disease (1-10). We previously reported proteomic profiling focused on HCC with HCV infection (6-8). These studies revealed that members of the heat shock protein 70 family, including heat shock $70-\mathrm{kDa}$ protein (Hsp70), heat shock cognate 71-kDa protein (Hsc71), 75-kDa glucoseregulated protein (GRP75) and 78-kDa glucose-regulated protein (GRP78), were all up-regulated in HCV-related HCC (6). Heat shock proteins are induced by various stresses and serve as molecular chaperones that function to maintain protein structure, transport proteins and aid in the formation of protein complexes, as well as playing a role in proteolysis (11).

Heat shock protein-binding protein 1 (HspBP1) was isolated and characterized as a protein which regulates Hsp70 activity. The expression of HspBP1 was shown to increase in mouse neuroblastoma and lung tumors (12-14). Here, we demonstrate that the changes in the protein expression of HspBP1 are correlated with changes in Hsp70 expression in human HCV-related HCC tissues, and discuss the biological significance of HspBP1 in HCC.

\section{Materials and methods}

Tissue specimens. Tumor and paired non-tumor liver specimens from 20 patients who had undergone partial hepatectomy at the Yamaguchi University Hospital for HCC between 1998 and 2000 were included in this study. The clinical tumor data of these patients is summarized in Table I. TNM staging was 
Table I. Clinical tumor data of HCC.

\begin{tabular}{|c|c|c|c|c|c|}
\hline No. & Main tumor size $(\mathrm{cm})$ & TNM stage $^{\mathrm{a}}$ & Differentiation & Vascular invasion & Mono/multi \\
\hline 1 & 2.8 & II & Moderate & Yes & Multi \\
\hline 2 & 2.5 & II & Moderate & No & Multi \\
\hline 3 & 2.5 & I & Well & Yes & Mono \\
\hline 4 & 12.0 & $\mathrm{IV}^{\mathrm{a}}$ & Moderate & No & Multi \\
\hline 5 & 5.0 & II & Moderate & Yes & Multi \\
\hline 6 & 7.0 & III & Moderate & No & Multi \\
\hline 7 & 2.9 & I & Moderate & No & Mono \\
\hline 8 & 3.4 & II & Poor & Yes & Multi \\
\hline 9 & 1.6 & I & Well & No & Mono \\
\hline 10 & 1.2 & I & Well & No & Mono \\
\hline 11 & 3.5 & II & Moderate & No & Multi \\
\hline 12 & 3.8 & I & Moderate & No & Mono \\
\hline 13 & 2.0 & II & Moderate & Yes & Multi \\
\hline 14 & 9.0 & II & Moderate & Yes & Mono \\
\hline 15 & 3.2 & II & Well & No & Mono \\
\hline 16 & 1.5 & III & Well & No & Multi \\
\hline 17 & 10.0 & $\mathrm{IV}^{\mathrm{a}}$ & Poor & Yes & Multi \\
\hline 18 & 8.5 & III & Poor & No & Multi \\
\hline 19 & 12.0 & $\mathrm{IV}^{\mathrm{a}}$ & Poor & Yes & Mono \\
\hline 20 & 2.5 & II & Poor & Yes & Mono \\
\hline
\end{tabular}

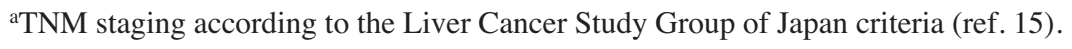

based on the criteria of the Liver Cancer Study Group of Japan (15). HCC tumors from 5, 10 and 5 patients were well, moderately and poorly-differentiated, respectively. All patients were serologically positive for anti-HCV antibody and negative for hepatitis B surface antigen. Normal control liver tissues were derived from patients without hepatitis who had undergone partial hepatectomy for metastatic liver tumors of colon cancer.

Sample preparation. Resected liver tissues were homogenized in lysis buffer (1\% NP-40, $1 \mathrm{mM}$ sodium vanadate, $1 \mathrm{mM}$ PMSF, $50 \mathrm{mM}$ Tris, $10 \mathrm{mM} \mathrm{NaF}, 10 \mathrm{mM}$ EDTA, $165 \mathrm{mM}$ $\mathrm{NaCl}, 10 \mu \mathrm{g} / \mathrm{ml}$ leupeptin and $10 \mu \mathrm{g} / \mathrm{ml}$ aprotinin) using a Potter type homogenizer with a Teflon tip and incubated at $4^{\circ} \mathrm{C}$ for $1 \mathrm{~h}$. The homogenate was separated by centrifugation at $15,000 \mathrm{x}$ g for $30 \mathrm{~min}$ to yield a supernatant and stored at $-80^{\circ} \mathrm{C}$ until used.

Immunoblotting. Protein samples $(20 \mu \mathrm{g})$ of the supernatant were submitted to SDS-PAGE. Proteins were separated on 10-20\% gradient polyacrylamide gels at $15 \mathrm{~mA} / \mathrm{gel}$. A control sample was included on each gel. After separation by SDSPAGE, proteins were transferred electrophoretically onto a polyvinylidene fluoride membrane (Immobilon; Millipore Corp., Bedford, MA), and the membranes were blocked overnight at $4^{\circ} \mathrm{C}$ with TBS containing $5 \%$ skim milk. The primary antibodies were goat anti-human Hsp70 antibody (1:200) (Santa Cruz Biotechnology, Santa Cruz, CA), $1 \mu \mathrm{g} / \mathrm{ml}$ sheep anti-HspBP1 antibody (Novus Biologicals, Littleton, $\mathrm{CO})$ and rabbit anti-actin antibody (1:200) (Santa Cruz Bio- technology). The membranes were incubated for $1 \mathrm{~h}$, rinsed four times with TBS containing $0.05 \%$ Tween-20 and visualized using a chemiluminescence reagent (ECL; Amersham Pharmacia Biotechnology, Uppsala, Sweden).

Image analysis. The positions of the protein bands on the gels were defined using an Agfa Arcus 1200 ${ }^{\mathrm{TM}}$ image scanner (Agfa-Gevaert N.V., Mortsel, Belgium) and analyzed with Image Gauge ver. 3.45 software (Fuji Film Science Lab, Minami Ashigara, Japan).

\section{Results}

The protein expression of Hsp70 and HspBP1 in tumor and non-tumor tissues from 20 patients bearing HCV-related HCC was investigated. The major HspBP1 band was $\sim 40 \mathrm{kDa}$ in size, but a slightly smaller band was also present in the samples analyzed (Fig. 1A). All analysis was conducted using the $40-\mathrm{kDa}$ upper band. The expression of Hsp70 and HspBP1 in tumor tissues was increased by $>1.5$-fold in 16 $(80 \%)$ of the patients and in $10(50 \%)$ of the patients, respectively. The levels of Hsp70 and HspBP1 were significantly elevated 3.55-fold (0.87-8.73) and 2.02-fold (0.66-6.53), respectively, in the tumor tissues compared to non-tumor tissues. Statistical analysis showed a significant increase in both Hsp70 and HspBP1 in HCC by the t-test (Fig. 1D and E). The increases in the levels of Hsp70 and HspBP1 in tumor and non-tumor tissues revealed a significant correlation in the 40 samples as shown in Fig. $2\left(\mathrm{R}^{2}=0.286\right.$, $\mathrm{p}<0.001)$. 
(A)

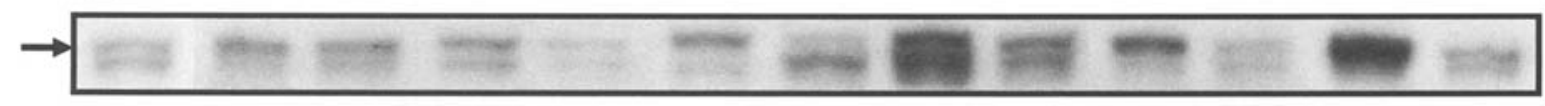

(B)

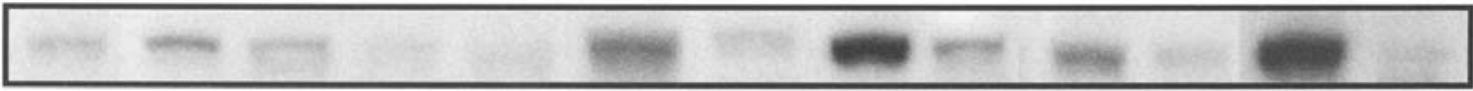

(C)

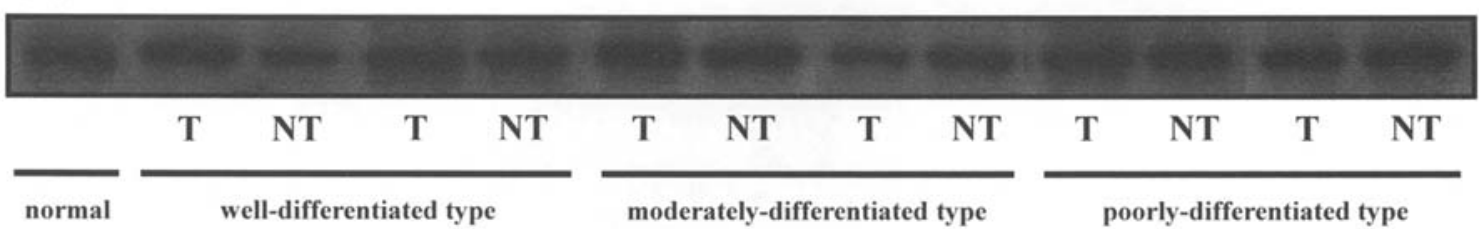

(D)

(E)
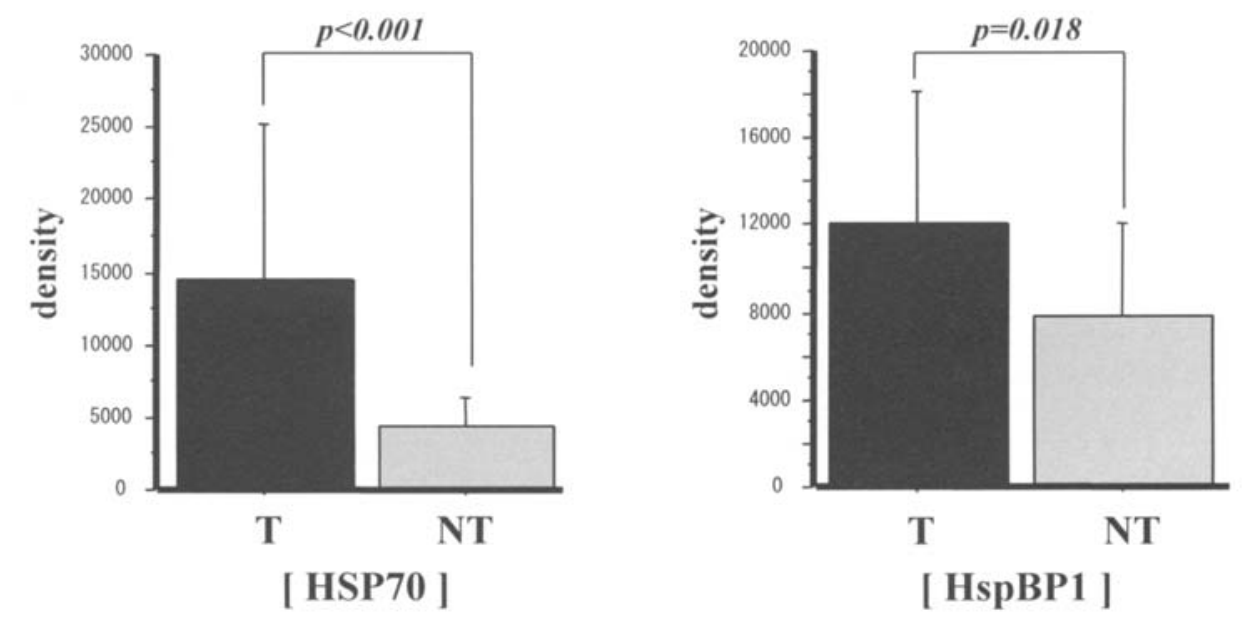

Figure 1. HspBP1 and Hsp70 levels in human HCC tissues. Western blot analysis was used to measure HspBP1 (A), Hsp70 (B), and actin (C) in tumor (T) and non-tumor (NT) tissues. Two representative samples of each type of differentiated HCC are shown. The arrow indicates the position of HspBP1. Normal tissues were obtained from patients who had undergone partial hepatectomy for metastatic liver tumors. Comparison of the amounts of Hsp70 (D) and HspBP1 (E) in tumor tissues vs. non-tumor tissues.

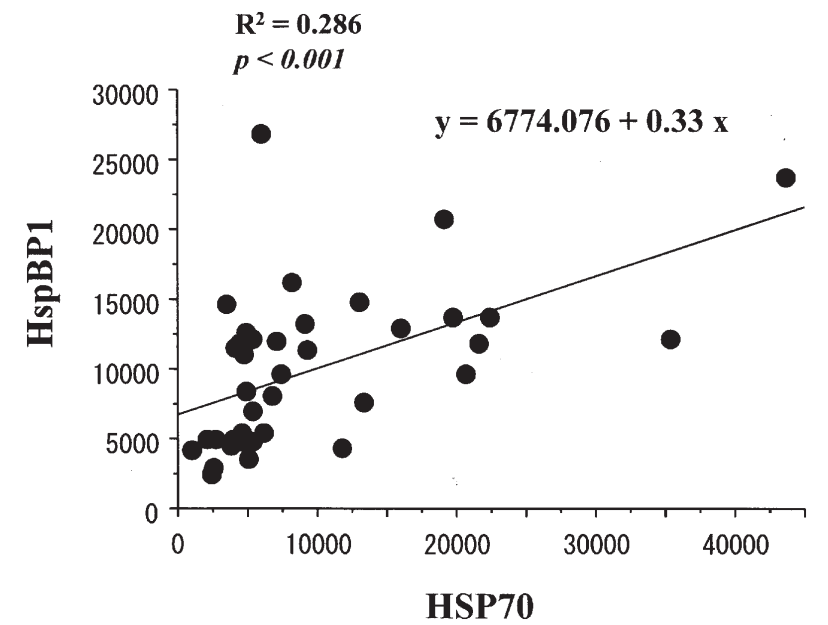

Figure 2. Correlation between the expression of HspBP1 and Hsp70. HspBP1 expression correlated with the expression of Hsp70 in tumor and non-tumor tissues $\left(\mathrm{p}<0.001, \mathrm{R}^{2}=0.286\right)$.
The correlation between the protein expression of Hsp70 and HspBP1 in tumor and non-tumor tissues and the clinical data of HCC, such as tumor size, staging, differentiation, vascular invasion and the number of tumors, was examined. Differentiation was the only feature that demonstrated a significant difference. Hsp70 was significantly up-regulated from the comparison of moderately-differentiated $\mathrm{HCC}$ with non-tumor tissues (Fig. 3). The expression of HspBP1 in HCC was higher in comparison to non-tumor tissues, but there was no significant difference among the groups. The relation between the ratio of expression of HspBP1 to Hsp70 in tumor tissues (HspBP1 T/HSP T) and clinical HCC data was investigated. There was a significant difference in this ratio for tumor size ( $<3 \mathrm{~cm}$ vs. $\geq 3 \mathrm{~cm}$ ) (Fig. 4). Large HCC had a lower ratio of HspBP1 T/HSP T. This ratio was lowest in moderately-differentiated HCC among the three types of differentiated HCC and significantly lower than in non-tumor tissues (Fig. 5). 
(A)

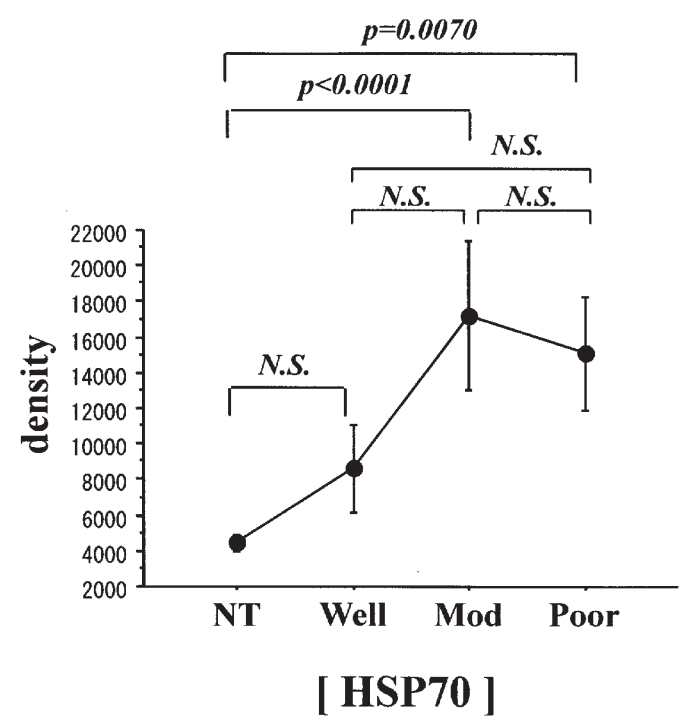

(B)

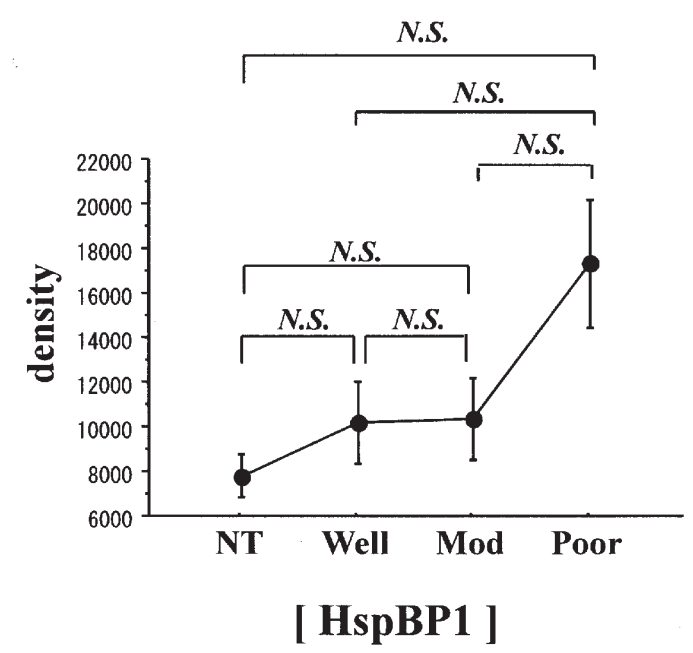

Figure 3. Quantitative analysis of the expression of Hsp70 (A) and HspBP1 (B) by type of differentiated HCC. This quantitative analysis was performed by ANOVA with the Bonferroni-Dunn test; $\mathrm{p}<0.0083$ was considered significant. The expression of HspBP1 demonstrated no significant difference among all groups although there was a significant difference between tumor (T) and non-tumor (NT) tissues as determined by the t-test (Fig. 1). The expression of Hsp70 was significantly up-regulated in moderately- (Mod) and poorly- (Poor) differentiated HCC compared to non-tumor tissues. N.S., no significant difference.

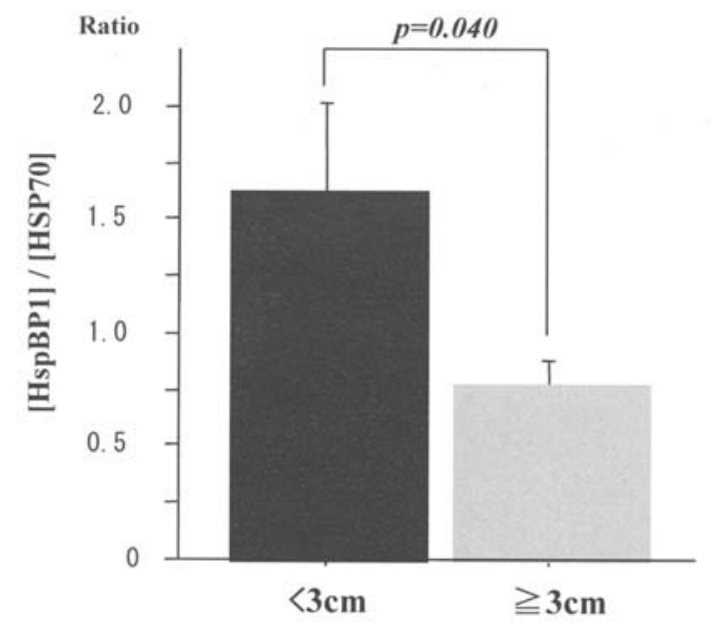

Figure 4. Correlation between the ratio of Hsp70 to HspBP1 and tumor size. The ratio of HspBP1 to Hsp70 in tumors $<3 \mathrm{~cm}$ and $\geq 3 \mathrm{~cm}$.

\section{Discussion}

We investigated the expression of Hsp70 and its inhibitor, HspBP1 in human HCV-related HCC tissues. Although the fluctuation of HspBP1 in tumors has been studied, until now, no study has been performed on human cancer tissues. For the first time, we analyzed the expression of HspBP1 in human $\mathrm{HCV}$-related HCC tissues, and demonstrated that it was increased in tumor compared to non-tumor tissues.

It is known that Hsp70 expression is increased in several cancer cell lines and tissues, such as HCV-related HCC $(6,16-21)$, and has been reported that the elevation of Hsp70 in certain cancer tissues leads to high malignant potential, poor prognosis or poor therapeutic outcome $(16,21,22)$. HspBP1 binds the ATPase domain of Hsp70 and inhibits its

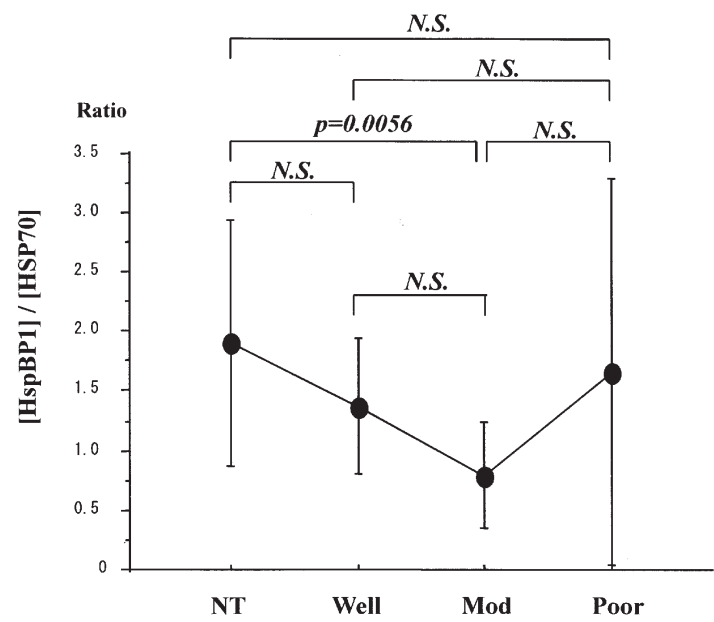

Figure 5. Quantitative analysis of the ratio of HspBP1 to Hsp70 in the types of differentiated HCC. This quantitative study was performed by ANOVA with the Bonferroni-Dunn test; $\mathrm{p}<0.0083$ was considered significant. The ratio was significantly lower in moderately-differentiated (Mod) compared to non-tumor (NT) tissues. N.S., no significant difference.

activity by nucleotide exchange (14). Hsp70 regulates cell growth or transformation in cancer cells $(23,24)$. Moreover, previous reports have revealed that Hsp70 in cancer tissues has an anti-apoptotic effect, and several studies have shown that increasing the level of Hsp70 prevents apoptosis whereas decreasing the level promotes it (23-28). One possibility is that the amount of HspBP1 in tumor tissues may decrease the anti-apoptotic effect of Hsp70.

The present study showed that the expression of Hsp70 and HspBP1 were correlated in human HCV-related HCC tissues. The expression of Hsp70 in cancer tissues from welldifferentiated to poorly-differentiated types was significantly increased compared with non-tumor tissues. In addition, the 
expression of HspBP1 in tumor tissues was significantly higher than in non-tumor tissues. However, it was evident that HspBP1 was not significantly up-regulated in poorlydifferentiated HCC. Previous data have demonstrated the importance of the ratio of the expression of HspBP1 to Hsp70 (12). The ratio in moderately-differentiated HCC had the lowest values among the three differentiated types. There was no significant difference in the ratio between non-tumor tissues and well-differentiated HCC. This ratio in poorly-differentiated $\mathrm{HCC}$ was greater than in moderately-differentiated HCC (Fig. 5). Although the reason for this discrepancy was unclear, these two proteins might have reacted differently to stress.

We investigated the relation between the ratio of HspBP1 to Hsp70 and HCC clinical data. The ratio showed a relationship to both tumor differentiation and tumor size. The ratio was significantly lower in larger tumors. These data indicate that the ratio of the expression of HspBP1 to Hsp70 may influence the progression of HCV-related HCC.

HspBP1 was up-regulated in human HCV-related HCC in this study, and therefore may have use as a tumor marker. Moreover, the ratio of the expression of HspBP1 to Hsp70 is a potentially important marker for tumor progression. The Hsp70 inhibitory activity of HspBP1 may provide a therapeutic means for controlling $\mathrm{HCC}$ by increasing HspBP1 or decreasing Hsp70, thereby regulating tumor growth or the apoptosis of tumor cells.

\section{References}

1. Park KS, Cho SY, Kim H and Paik YK: Proteomic alterations of the variants of human aldehyde dehydrogenase isozymes correlate with hepatocellular carcinoma. Int J Cancer 97: 261-265, 2002.

2. Park KS, Kim H, Kim NG, Cho SY, Choi KH, Seong JK and Paik YK: Proteomic analysis and molecular characterization of tissue ferritin light chain in hepatocellular carcinoma. Hepatology 35: 1459-1466, 2002.

3. Kim J, Kim SH, Lee SU, Ha GH, Kang DG, Ha NY, Ahn JS, Cho HY, Kang SJ, Lee YJ, Hong SC, Ha WS, Bae JM, Lee CW and Kim JW: Proteome analysis of human liver tumor tissue by two-dimensional gel electrophoresis and matrix-assisted laser desorption/ionization-mass spectrometry for identification of disease-related proteins. Electrophoresis 23: 4142-4156, 2002.

4. Lim SO, Park SJ, Kim W, Park SG, Kim HJ, Kim YI, Sohn TS, Noh JH and Jung G: Proteome analysis of hepatocellular carcinoma. Biochem Biophys Res Commun 291: 1031-1037, 2002.

5. Tannapfel A, Anhalt K, Hausermann P, Sommerer F, Benicke M, Uhlmann D, Witzigmann H, Hauss J and Wittekind C: Identification of novel proteins associated with hepatocellular carcinomas using protein microarrays. J Pathol 201: 238-249, 2003.

6. Takashima M, Kuramitsu Y, Yokoyama Y, Iizuka N, Toda T, Sakaida I, Okita K, Oka M and Nakamura K: Proteomic profiling of heat shock protein 70 family members as biomarkers for hepatitis $\mathrm{C}$ virus-related hepatocellular carcinoma. Proteomics 3: 2487-2493, 2003.

7. Yokoyama Y, Kuramitsu Y, Takashima M, Iizuka N, Toda T, Terai S, Sakaida I, Oka M, Nakamura K and Okita K: Proteomic profiling of proteins decreased in hepatocellular carcinoma from patients infected with hepatitis C virus. Proteomics 4: 2111-2116, 2004.

8. Takashima M, Kuramitsu Y, Yokoyama Y, lizuka N, Fujimoto M, Nishisaka T, Okita K, Oka M and Nakamura K: Overexpression of alpha enolase in hepatitis $\mathrm{C}$ virus-related hepatocellular carcinoma: Association with tumor progression as determined by proteomic analysis. Proteomics 5: 1686-1692, 2005.
9. Kim W, Oe Lim S, Kim JS, et al: Comparison of proteome between hepatitis B virus- and hepatitis $C$ virus-associated hepatocellular carcinoma. Clin Cancer Res 9: 5493-5500, 2003.

10. Liang CR, Leow CK, Neo JC, Tan GS, Lo SL, Lim JW, Seow TK, Lai PB and Chung MC: Proteome analysis of human hepatocellular carcinoma tissues by two-dimensional difference gel electrophoresis and mass spectrometry. Proteomics 5: 2258-2271, 2005.

11. Nollen EA and Morimoto RI: Chaperoning signaling pathways: Molecular chaperones as stress-sensing 'heat shock' proteins. J Cell Sci 115: 2809-2816, 2002.

12. Raynes DA, Graner MW, Bagatell R, McLellan C and Guerriero V: Increased expression of Hsp70 cochaperone HspBP1 in tumors. Tumour Biol 24: 281-285, 2003.

13. Raynes DA and Guerriero V Jr: Inhibition of Hsp70 ATPase activity and protein renaturation by a novel Hsp70-binding protein. J Biol Chem 273: 32883-32888, 1998.

14. Kabani M, McLellan C, Raynes DA, Guerriero V and Brodsky JL: HspBP1, a homologue of the yeast Fes1 and Sls1 proteins, is an Hsc70 nucleotide exchange factor. FEBS Lett 531: 339-342, 2002.

15. Kudo M, Chung H and Osaki Y: Prognostic staging system for hepatocellular carcinoma (CLIP score): its value and limitations, and a proposal for a new staging system, the Japan Integrated Staging Score (JIS score). J Gastroenterol 38: 207-215, 2003.

16. Chuma M, Sakamoto M, Yamazaki K, Ohta T, Ohki M, Asaka M and Hirohashi S: Expression profiling in multistage hepatocarcinogenesis: identification of HSP70 as a molecular marker of early hepatocellular carcinoma. Hepatology 37: 198-207, 2003.

17. Thanner F, Sutterlin MW, Kapp M, Rieger L, Kristen P, Dietl J, Gassel AM and Müller T: Heat-shock protein 70 as a prognostic marker in node-negative breast cancer. Anticancer Res 23: 1057-1062, 2003.

18. Cardoso F, Di Leo A, Larsimont D, Gancberg D, Rouas G, Dolci S, Ferreira F, Paesmans M and Piccart M: Evaluation of HER2, p53, bcl-2, topoisomerase II-alpha, heat shock proteins 27 and 70 in primary breast cancer and metastatic ipsilateral axillary lymph nodes. Ann Oncol 12: 615-620, 2001.

19. Isomoto H, Oka M, Yano Y, Kanazawa Y, Soda H, Terada R, Yasutake T, Nakayama T, Shikuwa S, Takeshima F, Udono H, Murata I, Ohtsuka K and Kohno S: Expression of heat shock protein (Hsp) 70 and Hsp 40 in gastric cancer. Cancer Lett 198: 219-228, 2003.

20. Maehara Y, Oki E, Abe T, Tokunaga E, Shibahara K, Kakeji Y and Sugimachi K: Overexpression of the heat shock protein Hsp70 family and p53 protein and prognosis for patients with gastric cancer. Oncology 58: 144-151, 2000.

21. Wang XP, Qiu FR, Liu GZ and Chen RF: Correlation between clinicopathology and expression of heat shock protein 70 and glucose-regulated protein 94 in human colonic adenocarcinoma. World J Gastroenterol 11: 1056-1059, 2005.

22. Beer DG, Kardia SL, Huang CC, Giordano TJ, Levin AM, Misek DE, Lin L, Chen G, Gharib TG, Thomas DG, Lizyness ML, Kuick R, Hayasaka S, Taylor JM, Iannettoni MD, Orringer MB and Hanash S: Gene-expression profiles predict survival of patients with lung adenocarcinoma. Nat Med 8: 816-824, 2002.

23. Kaur J, Kaur J and Ralhan R: Induction of apoptosis by abrogation of HSP70 expression in human oral cancer cells. Int J Cancer 85: $1-5,2000$.

24. Zhao ZG and Shen WL: Heat shock protein 70 antisense oligonucleotide inhibits cell growth and induces apoptosis in human gastric cancer cell line SGC-7901. World J Gastroenterol 11: 73-78, 2005.

25. Gabai VL, Zamulaeva IV, Mosin AF, Makarova YM, Mosina VA, Budagova KR, Malutina YV and Kabakov AE: Resistance of Ehrlich tumor cells to apoptosis can be due to accumulation of heat shock proteins. FEBS Lett 375: 21-26, 1995.

26. Mosser DD, Caron AW, Bourget L, Denis-Larose C and Massie B: Role of the human heat shock protein hsp70 in protection against stress-induced apoptosis. Mol Cell Biol 17: 5317-5327, 1997.

27. Buzzard KA, Giaccia AJ, Killender M and Anderson RL: Heat shock protein 72 modulates pathways of stress-induced apoptosis. J Biol Chem 273: 17147-17153, 1998.

28. Mosser DD, Caron AW, Bourget L, Meriin AB, Sherman MY, Morimoto RI and Massie B: The chaperone function of hsp70 is required for protection against stress-induced apoptosis. Mol Cell Biol 20: 7146-7159, 2000. 